\title{
Degradations of novel tetranuclear vanadyl glycollates to dinuclear species
}

\author{
Wan-Ting Jin, Xing Li, Zhao-Hui Zhou* \\ State Key Laboratory for Physical Chemistry of Solid Surfaces, College of Chemistry and \\ Chemical Engineering, Xiamen University, Xiamen, 361005, China
}

\begin{abstract}
Novel tetranuclear vanadyl glycollates $\left[\mathrm{Ni}(\text { phen })_{3}\right]_{2}\left[\mathrm{~V}^{\mathrm{IV}}{ }_{4} \mathrm{O}_{4}(\text { glyc })_{6}\right] \cdot 23 \mathrm{H}_{2} \mathrm{O} \quad$ (1) and $\left[\mathrm{Ni}(\text { phen })_{3}\right]_{2}\left[\mathrm{~V}^{\mathrm{IV}}{ }_{4} \mathrm{O}_{4}(\mathrm{glyc})_{6}\right] \cdot 16 \mathrm{H}_{2} \mathrm{O}$ (2) have been obtained through the capture of bulky nickel phenanthroline cation $\left(\mathrm{H}_{2} \mathrm{glyc}=\right.$ glycollic acid, phen $=1,10$-phenanthroline $)$, and the mixed-ligand complex $\left[\mathrm{V}^{\mathrm{IV}}{ }_{4} \mathrm{O}_{6}(\mathrm{glyc})_{2}(\mathrm{bpy})_{4}\right] \cdot 6 \mathrm{H}_{2} \mathrm{O}(3)$ (bpy $=2,2^{\prime}$-bipyridine) was isolated with the addition of bpy under hydrothermal condition. Tetrameric $\mathbf{1}$ and $\mathbf{2}$ are easily oxidized to dimeric complex $\left[\mathrm{Ni}(\text { phen })_{3}\right]\left[\mathrm{V}_{2}^{\mathrm{V}} \mathrm{O}_{4}(\mathrm{glyc})_{2}\right] \cdot 5 \mathrm{H}_{2} \mathrm{O}$ (4), while 3 with bipyridine is stable. The degradation process was traced by IR and XRD experiment. $1 \sim \mathbf{4}$ feature bidentate glycollate that chelates to vanadium atom through $\alpha$-alkoxy and $\alpha$-carboxy groups, which were full characterized by elemental analysis, TG, IR, UV-vis, EPR, XRD and X-ray structural analyses. Bond valence calculation is also performed.
\end{abstract}

Keywords: Glycollate; Vanadyl; Bipyridine; Nickel phenanthroline; Degradations.

\footnotetext{
* Corresponding author. Tel.: +86 592 2184531; fax: +86 5922183047.

E-mail address: zhzhou@xmu.edu.cn (Z.-H. Zhou).
} 


\section{Introduction}

The vanadium complexes are found with multi-applications in catalysis [1-3], medicine [4-6] as well as in biochemistry [7-9]. The discovery of the alternative vanadium-dependent nitrogenase have shown that cofactor of $\mathrm{V}$ nitrogenase containing homocitrate bidentately bound to vanadium in the active site, which is proposed analogous to Mo nitrogenase [10-12], and appears to have much better catalytic activity in the conversion of carbon monoxide to ethylene with over 93\% selectivity [13]. The peculiar properties prompted the studies of coordination chemistry of the model compounds for $R$-homocitrato vanadium complexes and its homologues.

Up to now, much work have been carried out to investigate the direct coordination chemistry of vanadium homocitrate [14,15], and its homologues citrate [15-27], malate [28, 29], lactate [28] or glycollate [28,30,31]. These $\alpha$-hydroxycarboxylates bind to the vanadium atom through their $\alpha$-alkoxy, $\alpha$-carboxy and/or $\beta$-carboxy groups. Vanadium $\alpha$-hydroxycarboxylates with unusual $\alpha$-hydroxy coordination are also reported $[29,32]$. These crystalline compounds have dimeric cores or mononuclear forms. Besides the X-ray crystal structure studies, a number of solution studies have been carried out on vanadium(IV,V) $\alpha$-hydroxycarboxylate systems, aiming to delineate the distributions of species involved in solution, where $\mathrm{VL}, \mathrm{V}_{2} \mathrm{~L}_{2}$ and $\mathrm{V}_{3} \mathrm{~L}_{2}$ products were proposed [33,34]. But vanadyl $\alpha$-hydroxycarboxylates with multinuclear forms are rare $[35,36]$. Here novel tetranuclear vanadium(V/IV) glycollates

$$
\left[\mathrm{Ni}(\mathrm{phen})_{3}\right]_{2}\left[\mathrm{~V}^{\mathrm{IV}}{ }_{4} \mathrm{O}_{4}(\mathrm{glyc})_{6}\right] \cdot 23 \mathrm{H}_{2} \mathrm{O}
$$

$\left[\mathrm{Ni}(\mathrm{phen})_{3}\right]_{2}\left[\mathrm{~V}^{\mathrm{IV}}{ }_{4} \mathrm{O}_{4}(\mathrm{glyc})_{6}\right] \cdot 16 \mathrm{H}_{2} \mathrm{O}(2)$ and $\left.\left[\mathrm{V}^{\mathrm{IV}}{ }_{4} \mathrm{O}_{6}(\mathrm{glyc})_{2} \text { (bpy }\right)_{4}\right] \cdot 6 \mathrm{H}_{2} \mathrm{O}(3)$ are reported with different configurations coordinated by $\alpha$-alkoxy and carboxy groups. The degradations of tetranuclear $\mathbf{1}$ and $\mathbf{2}$ to dinuclear vanadium(V) glycollate $\left[\mathrm{Ni}(\text { phen })_{3}\right]\left[\mathrm{V}_{2}^{\mathrm{V}}{ }_{2} \mathrm{O}_{4}(\mathrm{glyc})_{2}\right] \cdot 5 \mathrm{H}_{2} \mathrm{O}(\mathbf{4})$ in solid state and solution have been traced by IR and XRD experiments. 


\section{Experimental}

\subsection{Materials and instrumentation}

All solvents and reagents were of commercially analytical grade and used without further purification. Nanopure-quality water was used throughout this work. Elemental analyses (C, $\mathrm{H}$ and $\mathrm{N}$ ) were performed on a Vario EL III CHN elemental analyzer. TG analyses were performed on a TG 209F1 instrument in $\mathrm{N}_{2}$ atomosphere with a heating rate of $10{ }^{\circ} \mathrm{C} \mathrm{min}{ }^{-1}$. Infrared spectra were recorded in the range $400 \sim 4000 \mathrm{~cm}^{-1}$ on a Nicolet 380 FT-IR spectrometer in $\mathrm{KBr}$ plates. The solid diffused UV/Vis spectra were recorded at $293 \mathrm{~K}$ using a Cary 5000 UV-visible-NIR spectrophotometer in the $200 \sim 800 \mathrm{~nm}$ range. Solid electron paramagnetic resonance (EPR) spectra were analysed by a Bruker EMX-10/12 spectrometer using crystalline samples at $90 \mathrm{~K}$. pH value was determined by PHB-8 digital pH meter. X-ray powder diffraction (XRD) analysis was carried out on a Panalytical X'pert PRO diffractometer scanning $2 \theta$ from $4^{\circ}$ to $80^{\circ}$. Cu Ka radiation $(\lambda=1.5406 \AA$ ) obtained at $35 \mathrm{kV}$ and $15 \mathrm{~mA}$ was used as the X-ray source.

\subsection{Synthesis of $\left[\mathrm{Ni}(\text { phen })_{3}\right]_{2}\left[\mathrm{~V}_{4} \mathrm{O}_{4}(\mathrm{glyc})_{6}\right] \cdot 23 \mathrm{H}_{2} \mathrm{O}(\mathbf{1})$}

Nickel chloride hexahydrate $(79 \mathrm{mg}, 0.33 \mathrm{mmol})$ and phenanthroline monohydrate $(198 \mathrm{mg}$, $1.0 \mathrm{mmol})$ were dissolved in water-ethanol solution $(4.0 \mathrm{~mL}, 1: 1$ by volume). The solution was added to a mixture of excess glycollic acid $(228 \mathrm{mg}, 3.0 \mathrm{mmol})$, vanadyl sulfate $(217 \mathrm{mg}$, $1.33 \mathrm{mmol})$ and hydrazine hydrochloride $(53 \mathrm{mg}, 0.5 \mathrm{mmol})$ in water $(4.0 \mathrm{~mL})$. The $\mathrm{pH}$ value was adjusted to 6.0 with potassium hydroxide $(5.0 \mathrm{M})$. The mixture was stirred for 20 mins and evaporated at room temperature for several days. Deep-blue crystals were collected and washed with water to afford 1. Yield: (based on vanadium) $262 \mathrm{mg}(41.0 \%)$. Anal. Calc. for $\mathrm{C}_{84} \mathrm{H}_{106} \mathrm{~N}_{12} \mathrm{O}_{45} \mathrm{~V}_{4} \mathrm{Ni}_{2}:$ C, 43.4; H, 4.6; N, 7.2. Found: C, 43.0; H, 3.9; N, $6.9(\%)$. IR $\left(\mathrm{cm}^{-1}\right)$ : $v_{\mathrm{as}}\left(\mathrm{CO}_{2}\right), 1628 \mathrm{vs}, 1602 \mathrm{~s}, 1517 \mathrm{~s} ; \mathrm{v}_{\mathrm{s}}\left(\mathrm{CO}_{2}\right), 1425 \mathrm{~s}, 1356 \mathrm{~s} ; \mathrm{v}(\mathrm{V}=\mathrm{O}), 988 \mathrm{~s}, 935 \mathrm{~s} ; \mathrm{v}(\mathrm{V}-\mathrm{O}-\mathrm{V})$, $849 \mathrm{~m}$. 


\subsection{Synthesis of $\left[\mathrm{Ni}(\text { phen })_{3}\right]_{2}\left[\mathrm{~V}_{4} \mathrm{O}_{4}(\mathrm{glyc})_{6}\right] \cdot 16 \mathrm{H}_{2} \mathrm{O}(2)$}

Complex $\mathbf{2}$ was synthesized by the same procedure as $\mathbf{1}$ with the absence of hydrazine hydrochloride. The deep-blue crystals were collected and washed with water to afford 2 . Yield: (based on vanadium) $160 \mathrm{mg}\left(25.4 \%\right.$ ). Anal. Calc. for $\mathrm{C}_{84} \mathrm{H}_{92} \mathrm{~N}_{12} \mathrm{O}_{38} \mathrm{~V}_{4} \mathrm{Ni}_{2}: \mathrm{C}, 45.9 ; \mathrm{H}$, 4.2; N, 7.7. Found: C, 45.5; H, 4.1; N, $7.4(\%) . \mathrm{IR}\left(\mathrm{cm}^{-1}\right): v_{\text {as }}\left(\mathrm{CO}_{2}\right), 1647 \mathrm{~s}, 1517 \mathrm{~m} ; \mathrm{v}_{\mathrm{s}}\left(\mathrm{CO}_{2}\right)$, $1425 \mathrm{~s}, 1345 \mathrm{~m} ; \mathrm{v}(\mathrm{V}=\mathrm{O}), 983 \mathrm{~m}, 932 \mathrm{~s} ; \mathrm{v}(\mathrm{V}-\mathrm{O}-\mathrm{V}) 849 \mathrm{~m}$.

\subsection{Synthesis of $\left[\mathrm{V}_{4} \mathrm{O}_{6}(\mathrm{glyc})_{2}(\mathrm{bpy})_{4}\right] \cdot 6 \mathrm{H}_{2} \mathrm{O}(3)$.}

Vanadium pentoxide $\mathrm{V}_{2} \mathrm{O}_{5}(182 \mathrm{mg}, 1.0 \mathrm{mmol})$, excess glycollic acid $(230 \mathrm{mg}, 3.0 \mathrm{mmol})$, and 2,2'-bipyridine (160 mg, $1.0 \mathrm{mmol})$ were dissolved in water $(8.0 \mathrm{~mL})$ with continually stirring. The $\mathrm{pH}$ value was adjusted to 5.0 with dilute potassium hydroxide $(1.0 \mathrm{M})$. The mixture was placed in a Teflon-lined stainless steel bomb. The bomb was heated at $413 \mathrm{~K}$ for 4 days and cooled with programed control. The dark brown precipitates were collected and washed with ethanol to afford 3. Yield: (based on bpy) $86 \mathrm{mg},(28 \%)$. Anal. Calc. for $\mathrm{C}_{44} \mathrm{H}_{48} \mathrm{~N}_{8} \mathrm{O}_{18} \mathrm{~V}_{4}: \mathrm{C}, 44.7 ; \mathrm{H}, 4.1 ; \mathrm{N}$, 9.5. Found: $\mathrm{C}, 44.2 ; \mathrm{H}, 3.4 ; \mathrm{N}, 9.1(\%) . \mathrm{IR}\left(\mathrm{cm}^{-1}\right)$ : $v_{\text {as }}\left(\mathrm{CO}_{2}\right), 1602 \mathrm{~s} ; v_{\mathrm{s}}\left(\mathrm{CO}_{2}\right), 1380 \mathrm{~m} ; \mathrm{v}(\mathrm{V}=\mathrm{O}), 942 \mathrm{~s} ; \mathrm{v}(\mathrm{V}-\mathrm{O}-\mathrm{V}), 766 \mathrm{~s}$.

\subsection{Synthesis of $\left[\mathrm{Ni}(\text { phen })_{3}\right]\left[\mathrm{V}_{2} \mathrm{O}_{4}(\mathrm{glyc})_{2}\right] \cdot 5 \mathrm{H}_{2} \mathrm{O}(4)$}

The deep-blue crystals of $\mathbf{2}$ were set aside with their mother liquors for a half month, and pink crystals were collected and washed with water to afford of 4 . Yield: $220 \mathrm{mg}$ from 2 (43.9\%) (based on vanadium). Anal. Calc. for $\mathrm{C}_{40} \mathrm{H}_{38} \mathrm{O}_{15} \mathrm{~N}_{6} \mathrm{~V}_{2} \mathrm{Ni}$ : C, 47.9; $\mathrm{H}, 3.8 ; \mathrm{N}, 8.4$.

Found: C, 47.7; H, 3.5; N, $8.4(\%)$. IR $\left(\mathrm{cm}^{-1}\right): v_{\mathrm{as}}\left(\mathrm{CO}_{2}\right), 1654 \mathrm{~s}, 1587 \mathrm{~m}, 1517 \mathrm{~s} ; \mathrm{v}_{\mathrm{s}}\left(\mathrm{CO}_{2}\right)$, $1426 \mathrm{~s}, 1343 \mathrm{~s} ; \quad v(\mathrm{~V}=\mathrm{O}), 932 \mathrm{~s} ; \mathrm{v}(\mathrm{V}-\mathrm{O}-\mathrm{V}), 849 \mathrm{~s}$.

\subsection{X-ray crystallography}

The crystal data for $\mathbf{1} \sim \mathbf{4}$ were collected on an Oxford Gemini CCD diffractometer, with graphite monochromatic Mo-K $\alpha$ radiation $(\lambda=0.71073 \AA)$ at $173 \mathrm{~K}$. Muti-scan absorption corrections were applied. The structures were solved by direct methods and refined by 
full-matrix least-squares on $\mathrm{F}^{2}$ using the Shelxl crystallographic software package [37-39]. All non-hydrogen atoms were refined anisotropically, while hydrogen atoms were generated geometrically or located from differential Fourier maps and refined isotropically. For 1, 2 and 4, the unit cell includes a large region of disordered solvent water molecules respectively, which could not be modelled as discrete atomic sites. PLATON/SQUEEZE was employed to calculate the diffraction contribution of the solvent molecules, and to produce a set of solvent-free diffraction intensities. The SQUEEZE calculations showed a total solvent accessible area volume of $890.7 \AA^{3}$ in $\mathbf{1}, 618.8 \AA^{3}$ in $\mathbf{2}, 525.8 \AA^{3}$ in $\mathbf{4}$, and the residual electron density amounted to 229 e in $\mathbf{1}, 163$ e in $\mathbf{2}, 105$ e in $\mathbf{4}$ per unit cell, corresponding to nearly 23 molecules of water in 1, 16 molecules of water in $\mathbf{2}$ and 5 molecules of water in $\mathbf{4}$ respectively.

\section{Results and Discussion}

\subsection{Syntheses}

The reactions of vanadium sulfate with excess $\mathrm{H}_{2}$ glyc are sensitive to $\mathrm{pH}$ variations, as demonstrated by a digital pH monitor. $\mathbf{1}$ and $\mathbf{2}$ were obtained in weak acid solution. Decrease of $\mathrm{pH}$ value will result in the formation of an oxidized dimeric complex 4 . Hydrazine hydrochloride supposedly creates additional osmotic effects leading to a structure with higher water content in the formation of $\mathbf{1}$, while its absence will be suitable for the formation of $\mathbf{2}$. It is noteworthy that the products are trapped by bulky cation $\mathrm{Ni}(\mathrm{phen})^{2+}$ as countercation in aqueous solution. 3 was obtained through the hydrothermal process at $413 \mathrm{~K}$. One-pot reaction is preceded by the reaction of vanadium pentoxide and excess $\mathrm{H}_{2}$ glyc $(1: 3)$ in the presence of N-heterocycle ligand, where bipyridine should not be excess. $1 \sim \mathbf{4}$ are only slightly soluble in water. It is interesting to note that $\mathbf{1}$ and $\mathbf{2}$ can gradually transform to $\mathbf{4}$.

\subsection{Crystal structures of $1 \sim 4$}


The molecular structures of $\mathbf{1}, \mathbf{2}$ and $\mathbf{4}$ consist of $\left[\mathrm{Ni}(\mathrm{phen})_{3}\right]^{2+}$ cations, tetrameric anion of $\left[\mathrm{V}_{4} \mathrm{O}_{4}(\text { glyc })_{6}\right]^{2-}$ or dimeric anion $\left[\mathrm{V}_{2} \mathrm{O}_{4}(\text { glyc })_{2}\right]^{2-}$ and crystal water molecules, while 3 consists of a neutral tetrameric molecule and crystal water molecules. Detail crystallographic data are given in Table 1 . The ORTEP plots of the $\left[\mathrm{V}_{4} \mathrm{O}_{4}(\mathrm{glyc})_{6}\right]^{2-}$ anions in $\mathbf{1}$ and $\mathbf{2}$, and the neutral molecule of $\left[\mathrm{V}_{4} \mathrm{O}_{6}(\text { glyc })_{2}(\text { bpy })_{4}\right]$ in 3 are shown in Figures $1 \sim 3$. The ORTEP diagram of $\left[\mathrm{V}_{2} \mathrm{O}_{2}(\mathrm{glyc})_{2}\right]^{2-}$ anion in $\mathbf{4}$ is shown in Figure $\mathrm{S} 1$. The comparisons of their framworks are shown in Figure 4 for the dimeric and tetrameric complexes. Selected bond distances and angles for $\mathbf{1} \sim \mathbf{4}$ are listed in Tables $\mathrm{S} 1 \sim \mathrm{S} 4$.

[Table 1]

[Figures $1 \sim 4]$

The structure of tetranuclear anion in $\mathbf{1}$ can be considered as a coupling product of two asymmetric units $\left[\mathrm{VO}(\mathrm{glyc})_{2} \mathrm{VO}(\mathrm{glyc})\right]$. Each vanadium atom is hexa-coordinated in a distorted octahedral geometry. Besides the terminal oxygen, V1 atom is chelated by one glycollate, and V2 atom is chelated by two glycollates where one of its $\alpha$-alkoxy oxygen atoms bridges with neighboring V2a atom. Similar structure can be found in some vanadium alkoxides listed in Table S5. The $\mathrm{V}-\mathrm{O}(\mu 3$-alkoxido $)$ distances $(2.03 \sim 2.28 \AA)$ and $\mathrm{V}-\mathrm{O}(\mu 3$-alkoxido $)-\mathrm{V}$ angles $\left(95.6 \sim 105.3^{\circ}\right)$ in $\mathbf{1}$ are similar with those of common alkoxido(oxido)vanadium complexes (distances $1.94 \sim 2.41 \AA$ and angles $86.2 \sim 109.7^{\circ}$ ). The comparisons for the configurations of two $\mathrm{V}=\mathrm{O}_{\text {terminal }}$ groups [40] show that they contain the same modes of anti-coplanar, twist and syn-coplanar, except $\mathrm{V}^{3+}$ containing complexes. Moreover, the structure is outcome of the dense hexagonal packing of cations and anions. Such packing is widespread and can be found not only in alkoxides of vanadium but typical for all 3d metal alkoxides [41].

The structure of tetranuclear anion in $\mathbf{2}$ consists of one $\left[\mathrm{V}_{2} \mathrm{O}_{2}(\mathrm{glyc})_{2}\right]$ unit connected by two $\left[\mathrm{VO}(\mathrm{glyc})_{2}\right]$ units. The $\mathrm{V} 2$ atom exists in distorted octahedral configuration, which is chelated 
by a bidentate glycollate and its $\alpha$-alkoxy oxygen served as a bridging atom connects with $\mathrm{V} 2 \mathrm{a}$ atom. The $\mathrm{V} 1$ atom in $\left[\mathrm{VO}(\mathrm{glyc})_{2}\right]$ has a tetragonal geometry. It is coordinated by two glycollates via $\alpha$-alkoxy and carboxy oxygen atoms, forming two five membered chelate rings. The two units $\left[\mathrm{VO}(\mathrm{glyc})_{2}\right]$ coordinate to the two vanadium atoms of $\left[\mathrm{V}_{2} \mathrm{O}_{2}(\mathrm{glyc})_{2}\right]$ via their $\alpha$-alkoxy oxygens. Due to the same dense hexagonal packing mode of cations and anions, the structure of anion in $\mathbf{2}$ with a $\left[\mathrm{V}_{4} \mathrm{O}_{4}\right]$ ring is thus closely related to $\mathbf{1}$ (see Figure 4). In the $\left[\mathrm{V}_{4} \mathrm{O}_{4}\right]$ ring of $1, \mathrm{~V} 1$ connect with $\mathrm{O} 1$ with the distance of $2.251 \AA$, while $\mathrm{V} 1$ and $\mathrm{O} 8$ in complex 2 could not connect with each other because of the longer distance of $3.822 \AA$. The discrete of $\mathrm{V} 1$ and $\mathrm{O} 8$ in $\mathbf{2}$ is caused by the tetragonal coordination geometry of V1 atom.

Complex 3 consists of two trans-oxo- $\left[\mathrm{V}_{2} \mathrm{O}_{3}(\right.$ glyc $\left.)(\text { phen })_{2}\right]$ units. The vanadium atom in each unit exists in a distorted $\mathrm{N}_{2} \mathrm{O}_{4}$ octahedral geometry. Besides one terminal oxygen atom, V2 atom is coordinated by one glycollate through $\alpha$-carboxy and $\alpha$-alkoxy groups, where $\alpha$-alkoxy atom acts as a bridging group, two nitrogen atoms from bpy and one of the nitrogen atoms is at the trans-position of terminal oxygen, and a triply bridging oxygen atom which links with the other two vanadium centers. Besides the terminal oxygen atom, V1 atom is coordinated by two nitrogen atoms from bpy, one $\alpha$-alkoxy atom from glycollate and two bridging oxygen atoms. The V1...V1a distances are in the order of 3.083(2) $\AA$, a distance that implicates a weak interaction between two metal centers. Complex 3 has a ladder-like $\left[\mathrm{V}_{4} \mathrm{O}_{4}\right]$ ring. Locating at each side of the "ladder", two planes of bpy groups are generally parallel to each other and the average distance $3.711 \AA$ is longer than the distances $3.5726 \AA$ [42] and $3.4 \sim 3.5 \AA[43]$ reported in literatures.

\section{[Table 2]}

As shown in Tables $\mathrm{S} 1 \sim \mathrm{S} 4$, the $\mathrm{V}-\mathrm{O}$ distances in $\mathbf{1} \sim \mathbf{4}$ vary systematically. The short V-O distances in range $1.588(3) \sim 1.627(2) \AA$ are in agreement with the double-bond character. For the tetranuclear complexes of $\mathbf{1} \sim \mathbf{3}$, the V-O (alkoxy) distances with an 
average value of $2.040 \AA$ are comparable to that of $\mathrm{V}^{\mathrm{IV}}{ }_{2} \mathrm{O}_{2}$ binuclear complexes $(2.047 \mathrm{av} \AA)$. The $\mathrm{V}-\mathrm{O}$ (carboxy) distances $2.015 \AA$ are shorter than those of $\mathrm{V}^{\mathrm{IV}}{ }_{2} \mathrm{O}_{2}$ binuclear complexes (2.049 av $\AA$ ) reported in Table 2. For the dinuclear complex $\mathbf{4}$, the V-O (alkoxy) distances (1.982av $\AA$ ) and V-O (carboxy) distances (1.980av $\AA$ ) are comparable with the corresponding distances in $\mathrm{V}_{2}^{\mathrm{V}} \mathrm{O}_{4}$ core reported. In the vanadyl $\alpha$-hydroxycarboxylates, the bond distances of $\alpha$-alkoxy and $\alpha$-carboxy to vanadium(IV) are longer than those of $\operatorname{vanadium}(\mathrm{V})$ $\alpha$-hydroxycarboxylates, indicating weak binding of $\alpha$-alkoxy and $\alpha$-carboxy groups to the vanadium atom in low oxidation state. All of the reported $\mathrm{V}^{\mathrm{V} / \mathrm{IV}}-\mathrm{O}$ (alkoxy) and $\mathrm{V}^{\mathrm{V} / \mathrm{IV}}-\mathrm{O}$ (carboxy) distances are shorter than that found in V-nitrogenase $(2.15 \AA)$ in lower oxidation state.

The cations in $\mathbf{1}, \mathbf{2}$ and $\mathbf{4},\left[\mathrm{Ni}(\mathrm{phen})_{3}\right]^{2+}$ are composed of a common $\mathrm{Ni}(\mathrm{II})$ phenanthroline complex in an octahedral configuration. The two phen are parallel to each other and the rings of each phenanthroline are involved in $\pi-\pi$ stacking in an offset or parallel-displaced mode [44]. The anions and the cations of $\mathbf{1 , 2}$, and $\mathbf{4}$ fill each interspace while the neutral molecules of 3 stack by face-to-face $\pi-\pi$ interactions through parallel pyridine rings. The strong intermolecular interactions of $\mathbf{3}$ (interplanar distance $3.662 \AA$ ) contribute to the stability of the structure. The packing diagrams are shown in Figures S2 S5.

\section{3. $T G A$}

TGA curves of polycrystalline samples of $\mathbf{1}$ and $\mathbf{2}$ and derivative of mass loss are shown in Figures S6a and b. 1 and 2 lose about 16.4 wt. $\%$ and 12.4 wt. $\%$ at $110{ }^{\circ} \mathrm{C}$ respectively. The low water mass loses were caused by their dehydration in room temperature. Moreover, the decompositions occurred from 300 to $400{ }^{\circ} \mathrm{C}$ with mass $\%$ loses of $16.6 \%$ for $\mathbf{1}$ and $15.5 \%$ for 2 .

\subsection{IR and $U V$-visible spectroscopies}

FT-infrared spectra show well-resolved strong and sharp absorptions for the coordinated 
glycollates of $1 \sim 4$ in Figure S7. Antisymmetric stretching vibrations $v_{a s}\left(\mathrm{COO}^{-}\right)$are observed between 1517 and $1654 \mathrm{~cm}^{-1}$. The corresponding symmetric stretches $v_{\mathrm{s}}\left(\mathrm{COO}^{-}\right)$appear between 1343 and $1426 \mathrm{~cm}^{-1}$. All of the carboxy absorptions are shifted to lower frequencies with respect to those of free glycollic acid. The frequency difference $\Delta\left[v_{\text {as }}\left(\mathrm{COO}^{-}\right)-v_{\mathrm{s}}\left(\mathrm{COO}^{-}\right)\right]$ [45] was greater than $200 \mathrm{~cm}^{-1}$, which is consistent with the monodentate coordinated carboxy group, and in agreement with those observed from X-ray structural analysis. The aforementioned tentative assignments were in consonance with previous reports on $\alpha$-hydroxycarboxylato complexes $[14,15,17,21,28]$. Moreover, the peaks around $932 \sim 988$ $\mathrm{cm}^{-1}$ are assigned to $\mathrm{V}=\mathrm{O}$ bond, which is in consistent with the values observed for the $\mathrm{V}-\mathrm{O}$ containing dinuclear species $[14,18,21,30]$.

The solid diffused reflectance UV-visible spectra of $\mathbf{1}, \mathbf{2}$ and $\mathbf{4}$ show nearly the same absorptions around 216, 254, 296, $329 \mathrm{~nm}$ in Figure S8. Above $400 \mathrm{~nm}$, the weak absorptions can be observed at 580, 558 and 525 for $\mathbf{1}, \mathbf{2}$ and $\mathbf{4}$ respectively. $\mathbf{3}$ shows the absorptions at $215,256,296,329 \mathrm{~nm}$, and a wide absorption in the range of $360 \sim 600 \mathrm{~nm}$ respectively. The absorptions above $360 \mathrm{~nm}$ can be assigned for $\mathrm{d}-\mathrm{d}$ transitions of vanadium glycollate, and the features below $360 \mathrm{~nm}$ can be attributed to charge-transfer or $\pi \rightarrow \pi$ bands [46].

\subsection{Bond valence calculations}

Theoretical bond valence calculations $[47,48]$ give the valences $4.315,4.267$ for $\mathbf{1}, 4.261$, 4.390 for 2, 4.303, 4.204 for 3, and 5.145, 5.203 for $\mathbf{4}$ respectively, which indicate that $\mathrm{V}$ sites are in +4 oxidation state in $\mathbf{1} \sim \mathbf{3}$, and +5 oxidation state in $\mathbf{4}$. This is further supported by EPR experiment at $90 \mathrm{~K}$. The EPR spectra of $\mathbf{1}$ and $\mathbf{2}$ appear to be anisotropic while $\mathbf{3}$ appears to be isotropic as shown in Fig. 5. The vanadyl complexes of $\mathbf{1}$ and $\mathbf{2}$ display axis-symmetric EPR spectra, and the $g$ values obtained are $g_{/} 3.1061, g_{\perp} 1.9802, g 4.3356$ for 1 ; and $g_{/}$ 3.1663, $\mathrm{g}_{\perp} 1.9602, \mathrm{~g} 4.3361$ for $\mathbf{2}$ respectively. As for complex $\mathbf{3}$, the $\mathrm{g}$ value obtained is 1.9707. The bands centered on $\mathrm{g} 1.9802,1.9602,3.1061,3.1663$ and 1.9707 that exhibit $\mathrm{S}=$ 
$1 / 2$ signals, which are consistent with a $3 \mathrm{~d}^{1}$ metal center $\mathrm{V}^{4+}$. The weak bands centered on $\mathrm{g}$ 4.3356 and 4.3361 are signals of NMR tube (g 4.3371). However, none of the spectrum shows any resolved hyperfine structures determined by the ${ }^{51} \mathrm{~V}$ nuclear spin $(\mathrm{I}=7 / 2, \mathrm{~S}=1 / 2)$ [49]. The missing of hyperfine structures is presumably determined by strong spin-spin interactions and spin-orbit coupling interactions.

[Figure 5]

\section{Degradations of tetrameric vanadyl complexes to dimeric vanadate}

\subsection{Degradation in solution}

As stated in experimental section, crystals of $\mathbf{4}$ could be obtained from the solution of complex 2. Hence, XRD experiment was carried out to trace the degradation in solution from 2 to 4. In Figure 6, three strong peaks at $7.560,8.395$ and $10.500^{\circ}$ found in 2 (experiment) are consisitent with the simulated XRD pattern of 2 at $7.582,8.340$ and $10.478^{\circ}$. They weakened in $2 \mathrm{a}$ and $2 \mathrm{~b}$, and almost disappeared in $2 \mathrm{c}$. On the contrary, the peaks at $7.899^{\circ}$ and $10.116^{\circ}$ emerged in $2 \mathrm{a}$ and $2 \mathrm{~b}$ and become stronger in $2 \mathrm{c}$. They are corresponding to complex 4 at $7.838^{\circ}$ and $10.022^{\circ}$. It seems that the transformation happened in an early stage and almost completed after a half month.

\section{[Figure 6]}

\subsection{Degradation in solid state}

Besides the convertion in solution, degraduration can be also found in solid state. Tetrameric $\mathbf{1}$ in solid state was tracing by IR under heating condition. As shown in Figure 7, obvious changes can be observed in the range of 1120 and $930 \mathrm{~cm}^{-1}$ after $0.5 \mathrm{~h}$. The peaks at $1121,1061,990$ and $934 \mathrm{~cm}^{-1}$ weakened or even disappeared while the peaks at 1077 and 969 $\mathrm{cm}^{-1}$ strengthened. As time went on, the changes were small which indicate that the conversion takes place in the early stage. After $26 \mathrm{~h}$, the spectrum is very similar to that of the spectrum in 4. Inconsistent spectrum may be caused by the other product from the 
degradation in the oxidate process shown in equation (1). To further identify the finall product, the compound was washed with water, then collected to measure by XRD experiment. In Figure S9, the XRD pattern of the product is consisitent with that of complex 4. It confirms that dimeric vanadate is the finall product.

$$
\left[\mathrm{Ni}(\text { phen })_{3}\right]_{2}\left[\mathrm{~V}^{\mathrm{IV}}{ }_{4} \mathrm{O}_{4}(\text { glyc })_{6}\right]+\mathrm{O}_{2}+2 \mathrm{H}_{2} \mathrm{O} \longrightarrow 2\left[\mathrm{Ni}(\text { phen })_{3}\right]\left[\mathrm{V}_{2}^{\mathrm{V}} \mathrm{O}_{4}(\text { glyc })_{2}\right]+2 \mathrm{H}_{2} \text { glyc }
$$

[Figure 7]

As shown in the experimental section, vanadyl glycollates favor rhombic dimeric structure 4 as a stable framework [28,30,31,50 ]. The number of rhombic dimeric unit, to some extent, reflects the stability of the structure. As show in Figure 4, complex 1 contains five rhombus units, while 2 and $\mathbf{3}$ contain one and three rhombus unit respectively. It seems that the stability of $\mathbf{3}$ remains in middle among the three compounds. But in actually, $\mathbf{3}$ shows a special stability in the same condition (Figure S10) due to the hydrophobic packing by $\pi-\pi$ interaction, which is the result from strong binding heterocyclic ligands of bpy in the vanadium coordination shell.

\section{Conclusions}

In summary, we have obtained three novel tetranuclear vanadyl (IV) glycollates, where $\mathbf{1}$ and $\mathbf{2}$ are trapped by bulky nickel phenanthroline cations and $\mathbf{3}$ was isolated with the addition of bpy under hydrothermal condition. X-ray structural analyses of $\mathbf{1} \sim \mathbf{4}$ show that tetrameric and dimeric species existed in distorted octahedral, quadrangular pyramid and trigonal bipyramid configurations. Glycollate ligands coordinate bidentately to the central vanadium with $\alpha$-alkoxy and $\alpha$-carboxy oxygen atoms. The monodentate coordination of $\alpha$-carboxy group is supported by IR analysis. EPR spectra indicate that the vanadium sites are in +4 oxidation state in $\mathbf{1} \sim \mathbf{3}$ and +5 oxidation state in $\mathbf{4} . \mathbf{1}$ and $\mathbf{2}$ are vulnerable to be oxidized to dimeric 4, which was further traced by IR and XRD experiments, while $\mathbf{3}$ is stable due to the 
strongly binding N-heterocyclic ligand of bpy. The degradation process reflects a possible way of utilizing polyvanadium in biological process.

\section{Acknowledgements}

We thank the supports from the Foundation of State Key Laboratory of Coal Clean Utilization and Ecological Chemical Engineering (Grant No. 2016-16), National Science Foundation of Fujian (2016I0101) and research Funds for the Central Universities (No. 20720150041) for their generous financial supports. 


\section{References}

[1] M. Sutradhar, L.M.D.R.S. Martins, M.F.C. Guedes da Silva, A.J.L. Pombeiro, Coord. Chem. Rev., 301-302 (2015) 200-239.

[2] A.G.J. Ligtenbarg, R. Hage, B.L. Feringa, Coord. Chem. Rev., 237 (2003) 89-101.

[3] J.A.L. da Silva, J.J.R.F. da Silva, A.J.L. Pombeiro, Coord. Chem. Rev., 255 (2011) 2232-2248.

[4] G.R. Willsky, L.H. Chi, M. Godzala Iii, P.J. Kostyniak, J.J. Smee, A.M. Trujillo, J.A. Alfano, W. Ding, Z. Hu, D.C. Crans, Coord. Chem. Rev., 255 (2011) 2258-2269.

[5] J.C. Pessoa, S. Etcheverry, D. Gambino, Coord. Chem. Rev., 301-302 (2015) 24-48.

[6] E. Kioseoglou, S. Petanidis, C. Gabriel, A. Salifoglou, Coord. Chem.Rev., 301-302 (2015) 87-105.

[7] D. Rehder, Angew. Chem.-Int. Edit., 30 (1991) 148-167.

[8] D. Rehder, Coord. Chem. Rev., 182 (1999) 297-322.

[9] D. Rehder, Metallomics, 7 (2015) 730-742.

[10] J.M. Arber, B.R. Dobson, R.R. Eady, P. Stevens, S.S. Hasnain, C.D. Garner, B.E. Smith, Nature 325 (1987) 372-374.

[11] J.E. Morningstar, B.J. Hales, J. Am. Chem. Soc., 109 (1987) 6854-6855.

[12] J. Chen, J. Christiansen, R.C. Tittsworth, B.J. Hales, S.J. George, D. Coucouvanis, S.P. Cramer, J. Am. Chem. Soc., 115 (1993) 5509-5515.

[13] Y.L. Hu, C.C. Lee, M.W. Ribbe, Science, 333 (2011) 753-755.

[14] D.W. Wright, R.T. Chang, S.K. Mandal, W.H. Armstrong, W.H. Orme-Johnson, J. Biol. Inorg. Chem., 1 (1996) 143-151.

[15] C.Y. Chen, Z.H. Zhou, H.B. Chen, P.Q. Huang, K.R. Tsai, Y.L. Chow, Inorg. Chem., 47 (2008) 8714-8720.

[16] D.W. Wright, P.A. Humiston, W.H. Orme-Johnson, W.M. Davis, Inorg. Chem., 34 (1995) 4194-4197.

[17] Z.H. Zhou, H.L. Wan, S.Z. Hu, K.R. Tsai, Inorg. Chim. Acta, 237 (1995) 193-197.

[18] Z.H. Zhou, W.B. Yan, H.L. Wan, K.R. Tsai, J.Z. Wang, S.Z. Hu, J. Chem. Crystallogr., 25 (1995) 807-811.

[19] S. Burojevic, I. Shweky, A. Bino, D.A. Summers, R.C. Thompson, Inorg. Chim. Acta, 251 (1996) 75-79.

[20] M. Velayutham, B. Varghese, S. Subramanian, Inorg. Chem., 37 (1998) 1336-1340.

[21] Z.H. Zhou, H. Zhang, Y.Q. Jiang, D.H. Lin, H.L. Wan, K.R. Tsai, Transition Met. Chem. , 24 (1999) 605-609.

[22] M. Tsaramyrsi, M. Kaliva, A. Salifoglou, C.P. Raptopoulou, A. Terzis, V. Tangoulis, J. Giapintzakis, Inorg. Chem., 40 (2001) 5772-5779.

[23] M. Tsaramyrsi, D. Kavousanaki, C.P. Raptopoulou, A. Terzis, A. Salifoglou, Inorg. Chim. Acta, 320 (2001) 47-59.

[24] M. Kaliva, T. Giannadaki, A. Salifoglou, C.P. Raptopoulou, A. Terzis, Inorg. Chem., 41 (2002) 3850-3858.

[25] M. Kaliva, C.P. Raptopoulou, A. Terzis, A. Salifoglou, J. Inorg. Biochem., 93 (2003) 161-173.

[26] M. Aureliano, T. Tiago, R.M.C. Gandara, A. Sousa, A. Moderno, M. Kaliva, A. Salifoglou, R.O. Duarte, J.J.G. Moura, J. Inorg. Biochem., 99 (2005) 2355-2361.

[27] C.Y. Chen, Z.H. Zhou, S.Y. Mao, H.L. Wan, J. Coord. Chem., 60 (2007) 1419-1426.

[28] M. Biagioli, L. Strinna-Erre, G. Micera, A. Panzanelli, M. Zema, Inorg. Chim. Acta, 310 (2000) 1-9.

[29] C.Y. Chen, M.L. Chen, H.B. Chen, H.X. Wang, S.P. Cramer, Z.H. Zhou, J. Inorg. 
Biochem., 141 (2014) 114-120.

[30] Z.H. Zhou, J.Z. Wang, H.L. Wan, K.R. Tsai, Chem. Res. Chin. Univ., 10 (1994) $102-106$.

[31] L.R. Guilherme, A.C. Massabni, A. Cuin, L.A.A. Oliveira, E.E. Castellano, T.A. Heinrich, C.M. Costa-Neto, J. Coord. Chem., 62 (2009) 1561-1571.

[32] V. Jodaian, M. Mirzaei, M. Arca, M. Carla Aragoni, V. Lippolis, E. Tavakoli, N.S. Langeroodi, Inorg. Chim. Acta, 400 (2013) 107-114.

[33] A.S. Tracey, M.J. Gresser, K.M. Parkinson, Inorg. Chem., 26 (1987) 629-638.

[34] S. Hati, R.J. Batchelor, F.W.B. Einstein, A.S. Tracey, Inorg. Chem., 40 (2001) $6258-6265$.

[35] P. Schwendt, A.S. Tracey, J. Tatiersky, J. Galikova, Z. Zak, Inorg. Chem., (2007).

[36] P. Antal, P. Schwendt, J. Tatiersky, R. Gyepes, M. Drábik, Transition Met. Chem. , 39 (2014) 893-900.

[37] G.M. Sheldrick, Acta Cryst., A64 (2008) 112-122.

[38] O.V. Dolomanov, L.J. Bourhis, R.J. Gildea, J.A.K. Howard, H. Puschmann, J. Appl. Cryst., 42 (2009) 339-341.

[39] G.M. Sheldrick, Acta Cryst., C71 (2015) 3-8.

[40] W. Plass, Inorg. Chem., 36 (1997) 2200-2205.

[41] N.Y. Turova, E.P. Turevskaya, V.G. Kessler, M.I. Yanovskaya, The chemistry of metal alkoxides, Springer Science \& Business Media, 2006.

[42] G.L. Zhang, Y.T. Li, X.Q. Luo, Z.Y. Wu, Z. Anorg. Allg. Chem., 634 (2008) $1161-1165$.

[43] N. Marino, F. Lloret, M. Julve, R.P. Doyle, Dalton Trans., 40 (2011) 12248-12256.

[44] C. Janiak, Dalton Trans., (2000) 3885-3896.

[45] G.B. Deacon, R.J. Phillips, Coord. Chem. Rev., 33 (1980) 227-250.

[46] A.Y. Kovalevsky, M. Gembicky, I.V. Novozhilova, P. Coppens, Inorg. Chem., 42 (2003) 8794-8802.

[47] I.D. Brown, D. Altermatt, Acta Cryst., B41 (1985) 244-247.

[48] M.D. Chen, Z.H. Zhou, S.Z. Hu, Chin. Sci. Bull., 47 (2002) 978-981.

[49] T.S. Smith, R. LoBrutto, V.L. Pecoraro, Coord. Chem. Rev., 228 (2002) 1-18.

[50] M. Kaliva, E. Kyriakakis, A. Salifoglou, Inorg. Chem., 41 (2002) 7015-7023.

[51] S. Kodama, N. Taya, Y. Inoue, Y. Ishii, Inorg. Chem., 55 (2016) 6712-6718.

[52] I.S. Tidmarsh, E. Scales, P.R. Brearley, J. Wolowska, L. Sorace, A. Caneschi, R.H. Laye, E.J.L. McInnes, Inorg. Chem., 46 (2007) 9743-9753.

[53] E.C. Sanudo, A.A. Smith, P.V. Mason, M. Helliwell, G. Aromi, R.E.P. Winpenny, Dalton Trans., (2006) 1981-1987.

[54] M.J. Manos, A.J. Tasiopoulos, E.J. Tolis, N. Lalioti, J.D. Woollins, A.M.Z. Slawin, M.P. Sigalas, T.A. Kabanos, Chem. Eur. J., 9 (2003) 695-703.

[55] C.C. Lee, Y.L. Hu, M.W. Ribbe, Angew. Chem., 50 (2011) 5545-5547. 


\section{Figures and Table Options}

Figure 1. The ORTEP plot of the anion in $\left[\mathrm{Ni}(\text { phen })_{3}\right]_{2}\left[\mathrm{~V}_{4} \mathrm{O}_{4}(\mathrm{glyc})_{6}\right] \cdot 23 \mathrm{H}_{2} \mathrm{O}(\mathbf{1})$ at the $30 \%$ probability levels, showing incomplete double-cubane configuration.

Figure 2. The ORTEP plot of the anion in $\left[\mathrm{Ni}(\text { phen })_{3}\right]_{2}\left[\mathrm{~V}_{4} \mathrm{O}_{4}(\mathrm{glyc})_{6}\right] \cdot 16 \mathrm{H}_{2} \mathrm{O}(2)$ at the $30 \%$ probability levels, showing butterfly configuration.

Figure 3. The ORTEP plot of $\left[\mathrm{V}_{4} \mathrm{O}_{6}(\mathrm{glyc})_{2}(\mathrm{bpy})_{4}\right] \cdot 6 \mathrm{H}_{2} \mathrm{O}(3)$ at the $30 \%$ probability levels.

Figure 4. The framworks of $\left[\mathrm{Ni}(\mathrm{phen})_{3}\right]_{2}\left[\mathrm{~V}_{4} \mathrm{O}_{4}(\text { glyc })_{6}\right] \cdot 23 \mathrm{H}_{2} \mathrm{O}(\mathbf{1})$, $\left[\mathrm{Ni}(\text { phen })_{3}\right]_{2}\left[\mathrm{~V}_{4} \mathrm{O}_{4}(\text { glyc })_{6}\right] \cdot 16 \mathrm{H}_{2} \mathrm{O}(2),\left[\mathrm{V}_{4} \mathrm{O}_{6}(\text { glyc })_{2}(\text { bpy })_{4}\right] \cdot 6 \mathrm{H}_{2} \mathrm{O}(3)$ and $\left[\mathrm{Ni}(\text { phen })_{3}\right]\left[\mathrm{V}_{2} \mathrm{O}_{4}(\text { glyc })_{2}\right] \cdot 5 \mathrm{H}_{2} \mathrm{O}(4)$.

Figure 5. EPR spectra of solid $\left[\mathrm{Ni}(\text { phen })_{3}\right]_{2}\left[\mathrm{~V}_{4} \mathrm{O}_{4}(\text { glyc })_{6}\right] \cdot 23 \mathrm{H}_{2} \mathrm{O}(\mathbf{1})$ $\left[\mathrm{Ni}(\text { phen })_{3}\right]_{2}\left[\mathrm{~V}_{4} \mathrm{O}_{4}(\text { glyc })_{6}\right] \cdot 16 \mathrm{H}_{2} \mathrm{O}(2)$ and $\left[\mathrm{V}_{4} \mathrm{O}_{6}(\text { glyc })_{2}(\text { bpy })_{4}\right] \cdot 6 \mathrm{H}_{2} \mathrm{O}(3)$ at $90 \mathrm{~K}$.

Figure 6. Qualitative XRD tracing of the conversion from $\left[\mathrm{Ni}(\text { phen })_{3}\right]_{2}\left[\mathrm{~V}_{4} \mathrm{O}_{4}(\text { glyc })_{6}\right] \cdot 16 \mathrm{H}_{2} \mathrm{O}(2)$ to $\left[\mathrm{Ni}(\text { phen })_{3}\right]\left[\mathrm{V}_{2} \mathrm{O}_{4}(\text { glyc })_{2}\right] \cdot 5 \mathrm{H}_{2} \mathrm{O}(4)$ in solution at different times. $(2 \mathrm{a}, 2 \mathrm{~b}$ and $2 \mathrm{c}$ are the XRD patterns for the samples collected from solution after 1.5, 7 and 15 days).

Figure 7. Qualitative IR tracing of the conversion from $\left[\mathrm{Ni}(\mathrm{phen})_{3}\right]_{2}\left[\mathrm{~V}_{4} \mathrm{O}_{4}(\text { glyc })_{6}\right] \cdot 23 \mathrm{H}_{2} \mathrm{O}$ (1) to $\left[\mathrm{Ni}(\text { phen })_{3}\right]\left[\mathrm{V}_{2} \mathrm{O}_{4}(\mathrm{glyc})_{2}\right] \cdot 5 \mathrm{H}_{2} \mathrm{O}$ (4) in solid state at different times heated at $70{ }^{\circ} \mathrm{C}$.

Table 1. Crystallographic data for $\left[\mathrm{Ni}(\text { phen })_{3}\right]_{2}\left[\mathrm{~V}_{4} \mathrm{O}_{4}(\text { glyc })_{6}\right] \cdot 23 \mathrm{H}_{2} \mathrm{O}(\mathbf{1})$, $\left[\mathrm{Ni}(\text { phen })_{3}\right]_{2}\left[\mathrm{~V}_{4} \mathrm{O}_{4}(\text { glyc })_{6}\right] \cdot 16 \mathrm{H}_{2} \mathrm{O}(2),\left[\mathrm{V}_{4} \mathrm{O}_{6}(\text { glyc })_{2}(\text { bpy })_{4}\right] \cdot 6 \mathrm{H}_{2} \mathrm{O}(3)$ and $\left[\mathrm{Ni}(\text { phen })_{3}\right]\left[\mathrm{V}_{2} \mathrm{O}_{4}(\text { glyc })_{2}\right] \cdot 5 \mathrm{H}_{2} \mathrm{O}(4)$.

Table 2. Comparisons of $\mathrm{V}-\mathrm{O}$ distances $(\AA)$ in dimeric citrato, malato, lactato and glycollato vanadium complexes. 
Table 1. Crystallographic data for $\left[\mathrm{Ni}(\text { phen })_{3}\right]_{2}\left[\mathrm{~V}_{4} \mathrm{O}_{4}(\mathrm{glyc})_{6}\right] \cdot 23 \mathrm{H}_{2} \mathrm{O}(\mathbf{1}),\left[\mathrm{Ni}(\mathrm{phen})_{3}\right]_{2}\left[\mathrm{~V}_{4} \mathrm{O}_{4}(\mathrm{glyc})_{6}\right] \cdot 16 \mathrm{H}_{2} \mathrm{O}(\mathbf{2}),\left[\mathrm{V}_{4} \mathrm{O}_{6}\left(\mathrm{glyc}_{2}(\mathrm{bpy})_{4}\right] \cdot 6 \mathrm{H}_{2} \mathrm{O}(\mathbf{3})\right.$ and $\left[\mathrm{Ni}(\text { phen })_{3}\right]\left[\mathrm{V}_{2} \mathrm{O}_{4}(\text { glyc })_{2}\right] \cdot 5 \mathrm{H}_{2} \mathrm{O}(4)$

\begin{tabular}{|c|c|c|c|c|}
\hline & $\mathbf{1}$ & 2 & $\mathbf{3}$ & 4 \\
\hline Empirical formula & $\mathrm{C}_{84} \mathrm{H}_{106} \mathrm{~N}_{12} \mathrm{O}_{45} \mathrm{~V}_{4} \mathrm{Ni}_{2}$ & $\mathrm{C}_{84} \mathrm{H}_{92} \mathrm{~N}_{12} \mathrm{O}_{38} \mathrm{~V}_{4} \mathrm{Ni}_{2}$ & $\mathrm{C}_{44} \mathrm{H}_{48} \mathrm{~N}_{8} \mathrm{O}_{18} \mathrm{~V}_{4}$ & $\mathrm{C}_{40} \mathrm{H}_{38} \mathrm{O}_{15} \mathrm{~N}_{6} \mathrm{~V}_{2} \mathrm{Ni}$ \\
\hline Formula weight & 2324.98 & 2198.87 & 1180.66 & 1003.35 \\
\hline Temperature, $\mathrm{K}$ & \multicolumn{4}{|c|}{$173(2)$} \\
\hline Wavelength & \multicolumn{4}{|c|}{$0.71073 \mathrm{~A}$} \\
\hline Crystal system & Triclinic & Triclinic & Monoclinic & Triclinic \\
\hline Space group & $P \overline{1}$ & $P \overline{1}$ & $P 2{ }_{1} / \mathrm{c}$ & $P \overline{1}$ \\
\hline \multicolumn{5}{|l|}{ Unit cell dimensions } \\
\hline $\mathrm{a}, \AA$ & $13.5345(7)$ & $12.468(1)$ & $12.8063(9)$ & $12.4886(4)$ \\
\hline $\mathrm{b}, \AA$ & $14.5915(8)$ & $14.3664(9)$ & $9.5831(4)$ & $13.6362(5)$ \\
\hline $\mathrm{c}, \AA$ & $15.7255(6)$ & $15.359(1)$ & $20.064(1)$ & $14.9658(5)$ \\
\hline$\alpha,{ }^{o}$ & 109.657(4) & $106.509(7)$ & 90 & $76.898(3)$ \\
\hline$\beta,^{\circ}$ & $104.259(4)$ & $101.800(7)$ & $102.874(6)$ & $66.721(3)$ \\
\hline$\gamma,{ }^{o}$ & $105.151(5)$ & $102.881(6)$ & 90 & $75.259(3)$ \\
\hline
\end{tabular}




\begin{tabular}{|c|c|c|c|c|}
\hline$V, \AA^{3}$ & $2625.2(2)$ & $2463.5(4)$ & $2400.4(3)$ & $2241.2(2)$ \\
\hline$Z$ & 1 & 1 & 2 & 2 \\
\hline$D$ (calculated), $\mathrm{g} / \mathrm{cm}^{3}$ & 1.471 & 1.482 & 1.634 & 1.487 \\
\hline Abs. coeff., $\mathrm{mm}^{-1}$ & 0.787 & 0.829 & 0.840 & 0.898 \\
\hline$F(000)$ & 1202.0 & 1132.0 & 1208 & 1028.0 \\
\hline Crystal size, $\mathrm{mm}$ & $0.20 \times 0.20 \times 0.15$ & $0.30 \times 0.25 \times 0.10$ & $0.20 \times 0.16 \times 0.06$ & $0.30 \times 0.30 \times 0.20$ \\
\hline$\theta$ range for data collection, ${ }^{\circ}$ & $2.91 \sim 29.99$ & $2.91 \sim 29.98$ & $2.92 \sim 27.00$ & $2.994 \sim 30.04$ \\
\hline Reflections collected & 21126 & 22756 & 10902 & 21148 \\
\hline Independent reflections & 10300 & 12320 & 5170 & 11319 \\
\hline$R_{\text {int }}$ & 0.0434 & 0.0477 & 0.0707 & 0.0221 \\
\hline Data / restraints / parameters & $10300 / 0$ / 559 & $12320 / 0 / 559$ & $5170 / 0$ / 334 & $11319 / 0 / 540$ \\
\hline GOF on $F^{2}$ & 1.097 & 1.067 & 1.022 & 1.033 \\
\hline Final $R$ indices $R_{1}[I>2 \sigma(I)]$ & 0.0579 & 0.0748 & 0.0981 & 0.0418 \\
\hline$R_{2}[I>2 \sigma(I)]$ & 0.1356 & 0.1546 & 0.2233 & 0.1105 \\
\hline $\begin{array}{l}\text { Largest diff. peak and hole, } \\
\qquad \mathrm{e}^{-3}\end{array}$ & $0.37 /-0.43$ & $0.42 /-0.62$ & $1.221 /-0.839$ & $0.41 /-0.41$ \\
\hline
\end{tabular}


Table 2. Comparisons of V-O distances $(\AA)$ in dimeric citrato, malato, lactato and glycollato vanadium complexes.

\begin{tabular}{llll}
\hline \multicolumn{1}{c}{ Complex } & $\begin{array}{l}\mathrm{V}-\mathrm{O} \\
(\alpha \text {-alkoxy })\end{array}$ & $\begin{array}{l}\mathrm{V}-\mathrm{O} \\
(\alpha \text {-carboxy })\end{array}$ & $\begin{array}{l}\mathrm{V}-\mathrm{O} \\
\square(\beta \text {-carboxy })\end{array}$ \\
\hline$\left[\mathrm{Ni}(\text { phen })_{3}\right]_{2}\left[\mathrm{~V}_{4} \mathrm{O}_{4}(\text { glyc })_{6}\right] \cdot 23 \mathrm{H}_{2} \mathrm{O}(\mathbf{1})$ & $2.080(3)_{\mathrm{av}}$ & $2.001(3)_{\mathrm{av}}$ & This work \\
{$\left[\mathrm{Ni}(\text { phen })_{3}\right]_{2}\left[\mathrm{~V}_{4} \mathrm{O}_{4}(\text { glyc })_{6}\right] \cdot 16 \mathrm{H}_{2} \mathrm{O}(\mathbf{2})$} & $2.016(3)_{\mathrm{av}}$ & $1.999(3)_{\mathrm{av}}$ & This work \\
{$\left[\mathrm{V}_{4} \mathrm{O}_{6}(\text { glyc })_{2}(\text { bpy })_{4}\right] \cdot 6 \mathrm{H}_{2} \mathrm{O}(\mathbf{3})$} & $2.024(5)_{\mathrm{av}}$ & $2.045(5)$ & This work \\
Average & $\mathbf{2 . 0 4 0 ( 5 )}$ & $\mathbf{2 . 0 1 5 ( 5 )}$ &
\end{tabular}

V(IV)

$\begin{array}{lllll}\mathrm{K}_{3}\left[\mathrm{~V}_{2} \mathrm{O}_{2} \mathrm{H}(\mathrm{cit})_{2}\right] \cdot 7 \mathrm{H}_{2} \mathrm{O} & 1.976(5)_{\mathrm{av}} & 1.981(6) & 1.976(7)_{\mathrm{av}} & {[22]} \\ (\mathrm{Hneo})_{3}\left[\mathrm{~V}_{2} \mathrm{O}_{2} \mathrm{H}(\mathrm{cit})_{2}\right] \cdot 4 \mathrm{H}_{2} \mathrm{O} & 1.984(4)_{\mathrm{av}} & 2.137(4)_{\mathrm{av}} & 1.989(4)_{\mathrm{av}} & {[19]} \\ \mathrm{Na}_{4}\left[\mathrm{~V}_{2} \mathrm{O}_{2}(\mathrm{cit})_{2}\right] \cdot 6 \mathrm{H}_{2} \mathrm{O} & 2.089(2)_{\mathrm{av}} & 2.038(2) & 2.025(2)_{\mathrm{av}} & {[17]} \\ \mathrm{Na}_{4}\left[\mathrm{~V}_{2} \mathrm{O}_{2}(\mathrm{cit})_{2}\right] \cdot 12 \mathrm{H}_{2} \mathrm{O} & 2.108(2)_{\mathrm{av}} & 2.039(2) & 2.017(2)_{\mathrm{av}} & {[22]} \\ \left(\mathrm{NH}_{4}\right)_{4}\left[\mathrm{~V}_{2} \mathrm{O}_{2}(\mathrm{cit})_{2}\right] \cdot 2 \mathrm{H}_{2} \mathrm{O} & 2.077(2)_{\mathrm{av}} & 2.049(2)_{\mathrm{av}} & 2.029(2)_{\mathrm{av}} & {[22]} \\ \text { Average } & \mathbf{2 . 0 4 7 ( 5 )} & \mathbf{2 . 0 4 9 ( 6 )} & \mathbf{2 . 0 0 7 ( 7 )} & \end{array}$

$\mathrm{V}(\mathrm{V})$

$\left[\mathrm{Ni}(\text { phen })_{3}\right]\left[\mathrm{V}_{2} \mathrm{O}_{4}(\mathrm{glyc})_{2}\right] \cdot 5 \mathrm{H}_{2} \mathrm{O}(\mathbf{4}) \quad 1.982(2)_{\mathrm{av}} \quad 1.980(2)_{\mathrm{av}} \quad$ This work

$\mathrm{Cs}_{2}\left[\mathrm{~V}_{2} \mathrm{O}_{4}(\mathrm{lact})_{2}\right] \cdot 2 \mathrm{H}_{2} \mathrm{O} \quad 1.979(4)_{\mathrm{av}} \quad 1.977(4)_{\mathrm{av}} \quad$ [28]

$\mathrm{K}_{2}\left[\mathrm{~V}_{2} \mathrm{O}_{4}(\text { glyc })_{2}\right]$

$\left(\mathrm{NH}_{4}\right)_{2}\left[\mathrm{~V}_{2} \mathrm{O}_{4}(\text { glyc })_{2}\right] \quad 1.978(5)_{\mathrm{av}} \quad 1.993(6)_{\mathrm{av}} \quad$ [30]

$\begin{array}{llll}\mathrm{Rb}_{2}\left[\mathrm{~V}_{2} \mathrm{O}_{4}(\mathrm{glyc})_{2}\right] & 1.980(2)_{\mathrm{av}} & 1.979(2)\end{array}$

$\mathrm{Cs}_{2}\left[\mathrm{~V}_{2} \mathrm{O}_{4}(\mathrm{Hmal})_{2}\right]$ 


$\begin{array}{llll}\mathrm{K}_{2}\left[\mathrm{~V}_{2} \mathrm{O}_{4}\left(\mathrm{H}_{2} \mathrm{cit}\right)_{2}\right] \cdot 4 \mathrm{H}_{2} \mathrm{O} & 1.986(2)_{\mathrm{av}} & 1.980(3) & {[16,18]} \\ \left(\mathrm{NH}_{4}\right)_{2}\left[\mathrm{~V}_{2} \mathrm{O}_{4}\left(\mathrm{H}_{2} \mathrm{cit}\right)_{2}\right] \cdot 2 \mathrm{H}_{2} \mathrm{O} & 1.988(2)_{\mathrm{av}} & 1.974(3) & {[18]} \\ \mathrm{Na}_{2}\left[\mathrm{~V}_{2} \mathrm{O}_{4}\left(\mathrm{H}_{2} \mathrm{cit}\right)_{2}\right] \cdot 2 \mathrm{H}_{2} \mathrm{O} & 1.984(3) & 1.957(3) & {[23]} \\ \mathrm{Na}_{2} \mathrm{~K}_{2}\left[\mathrm{~V}_{2} \mathrm{O}_{4}(\mathrm{Hcit})_{2}\right] \cdot 9 \mathrm{H}_{2} \mathrm{O} & 1.984(4)_{\mathrm{av}} & 1.979(4)_{\mathrm{av}} & {[21]} \\ \mathrm{K}_{4}\left[\mathrm{~V}_{2} \mathrm{O}_{4}(\mathrm{Hcit})_{2}\right] \cdot 5.6 \mathrm{H}_{2} \mathrm{O} & 1.994(2)_{\mathrm{av}} & 1.966(2) & {[24]} \\ \left(\mathrm{NH}_{4}\right)_{4}\left[\mathrm{~V}_{2} \mathrm{O}_{4}(\mathrm{Hcit})_{2}\right] \cdot 4 \mathrm{H}_{2} \mathrm{O} & 1.997(1)_{\mathrm{av}} & 1.977(2) & {[17,26]} \\ \mathrm{K}_{2}\left(\mathrm{NH}_{4}\right)_{4}\left[\mathrm{~V}_{2} \mathrm{O}_{4}(\mathrm{cit})_{2}\right] \cdot 6 \mathrm{H}_{2} \mathrm{O} & 1.983(2)_{\mathrm{av}} & 1.981(2) & {[25]} \\ \left(\mathrm{NH}_{4}\right)_{6}\left[\mathrm{~V}_{2} \mathrm{O}_{4}(\mathrm{cit})_{2}\right] \cdot 6 \mathrm{H}_{2} \mathrm{O} & 1.984(2)_{\mathrm{av}} & 1.981(2) & {[14]} \\ \mathrm{K}_{2}\left[\mathrm{~V}_{2} \mathrm{O}_{4}\left(R, S-\mathrm{H}_{2} \mathrm{homocit}\right)_{2}\right] \cdot 6 \mathrm{H}_{2} \mathrm{O} & 1.980(8)_{\mathrm{av}} & 1.959(8)_{\mathrm{av}} & \\ \text { Average } & \mathbf{1 . 9 8 5 ( 8 )} & \mathbf{1 . 9 7 5 ( 8 )} & \end{array}$




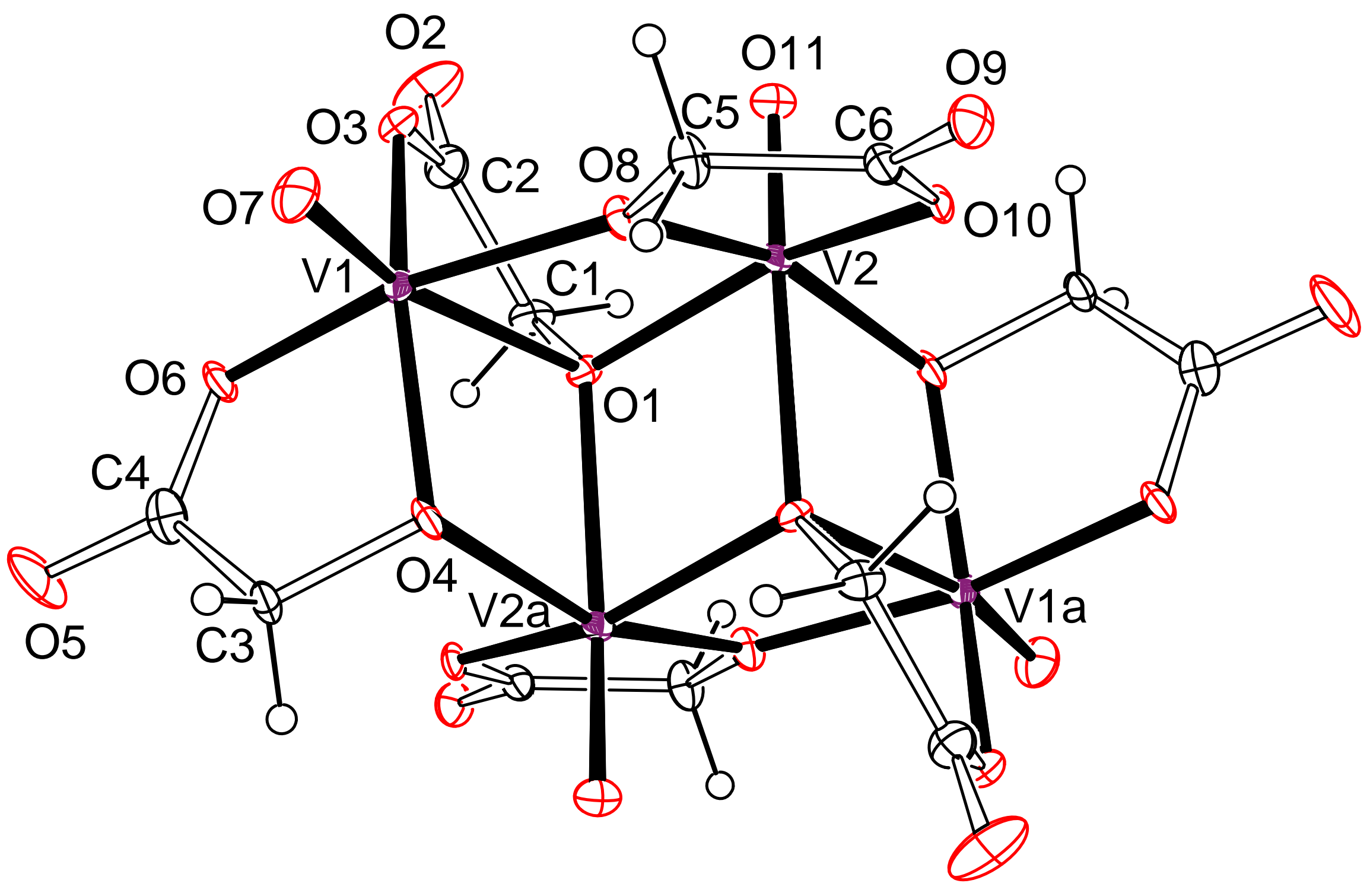




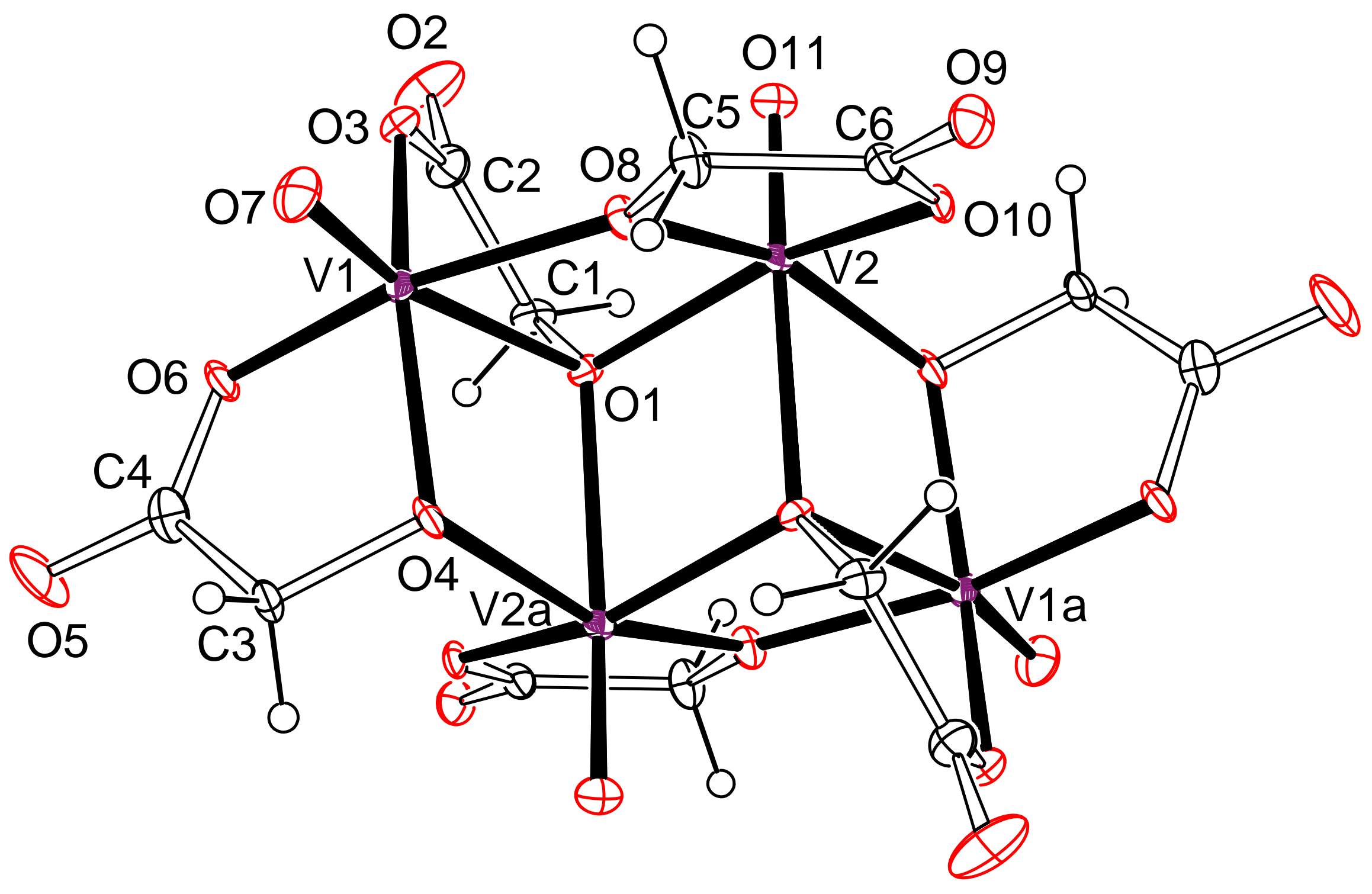


O5

Q

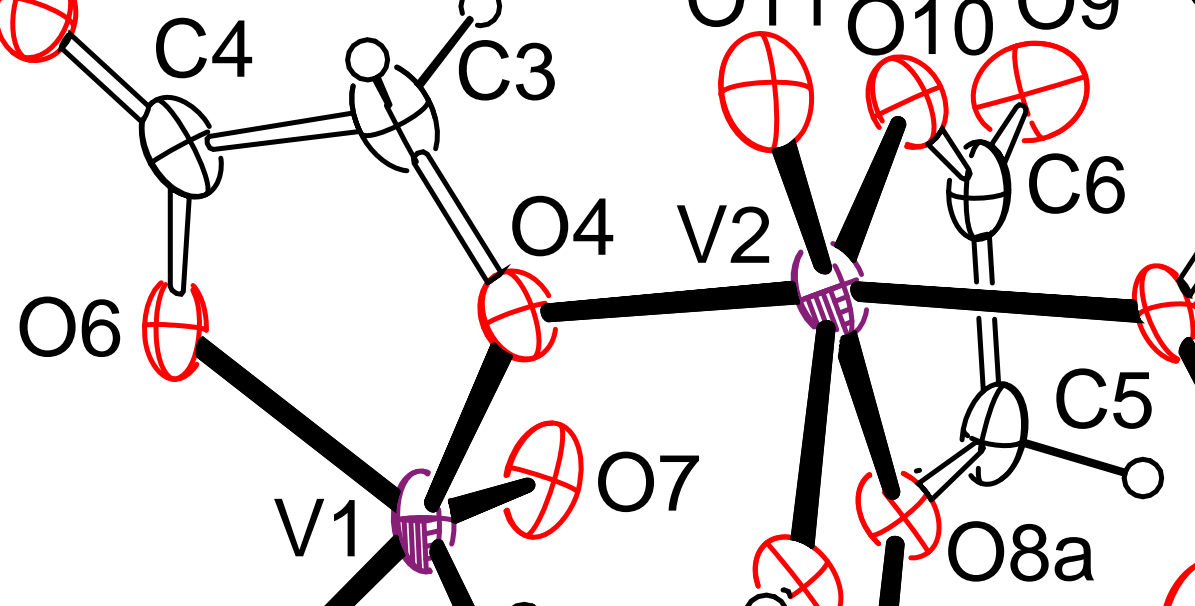

(2a

- $\quad 10 \otimes$

$\mathrm{O} 2$

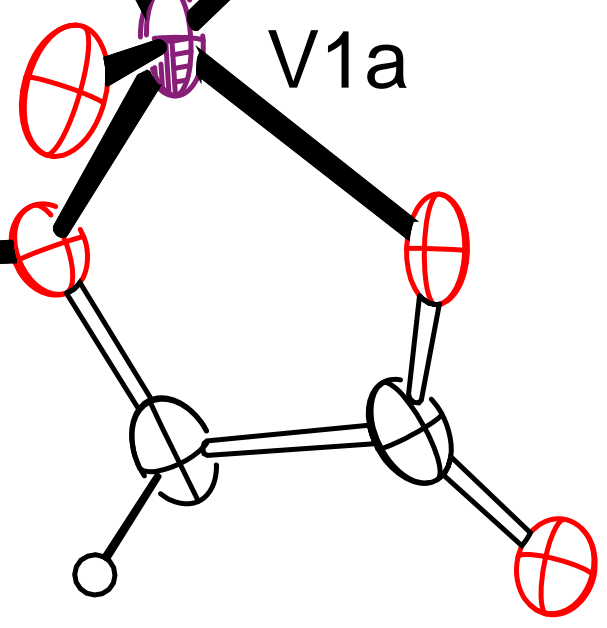




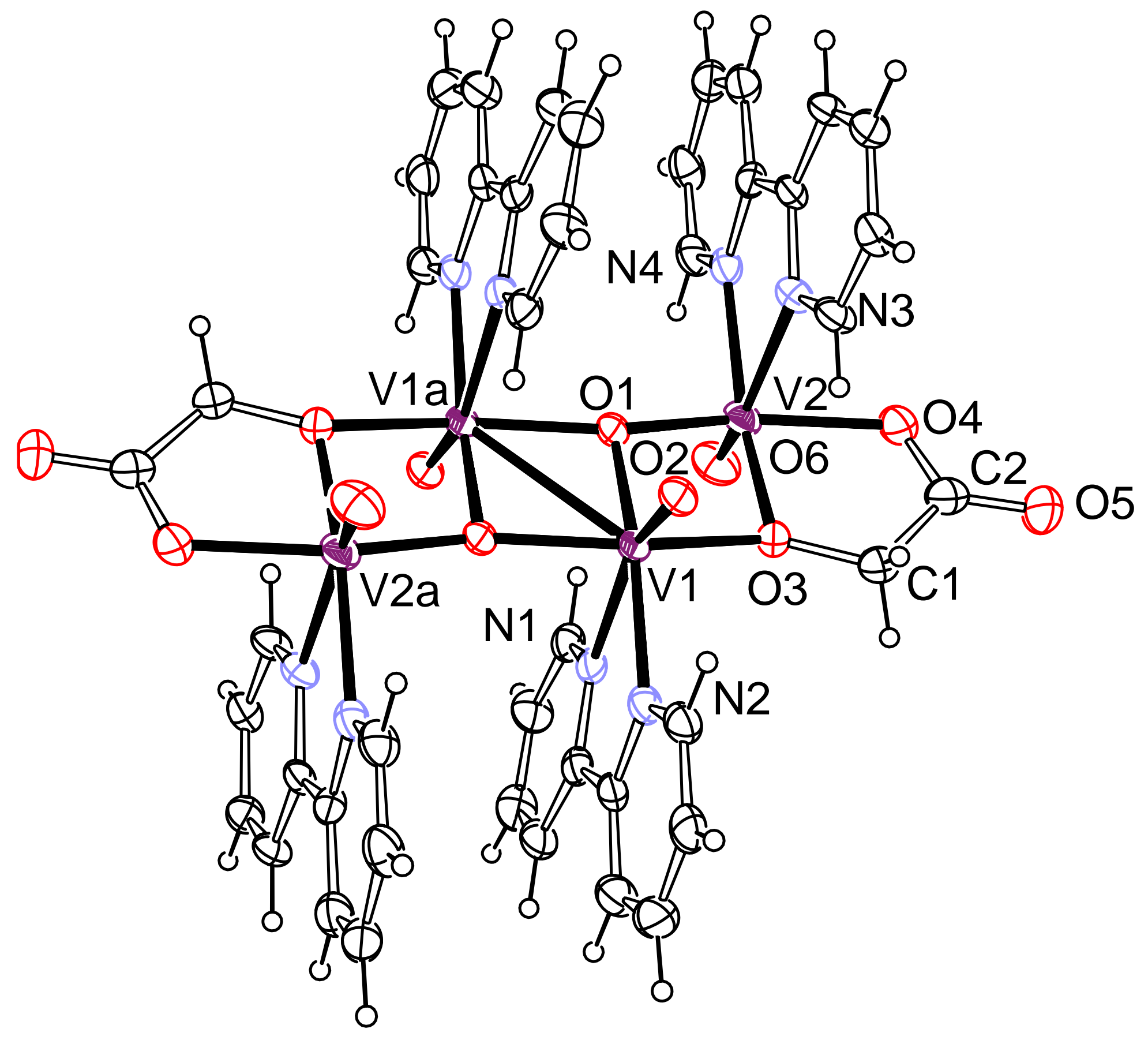




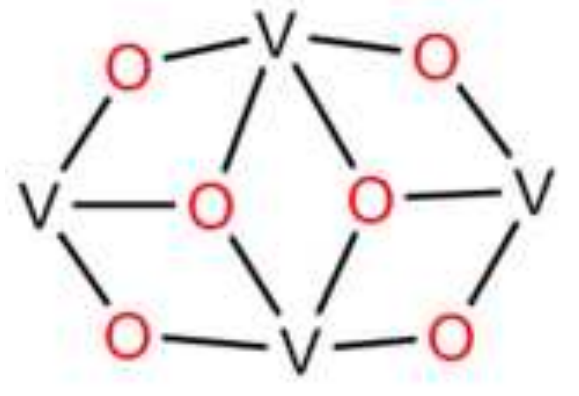

(1)

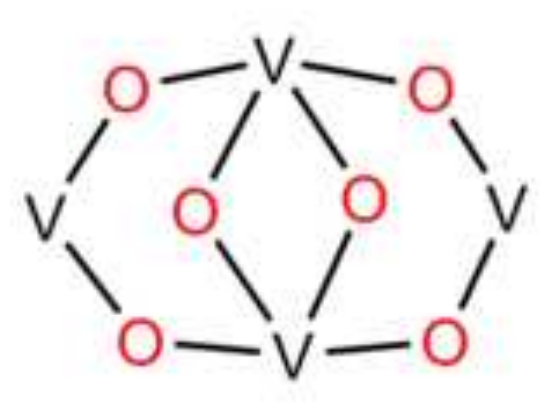

(2)

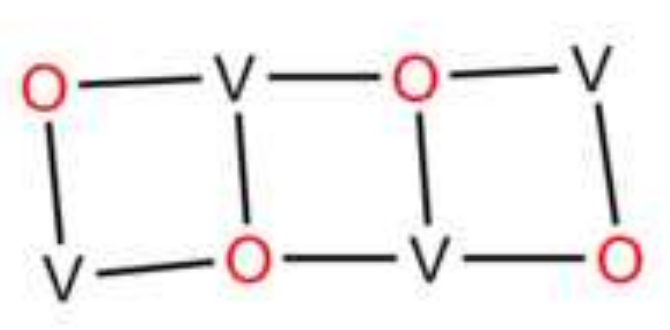

(3)

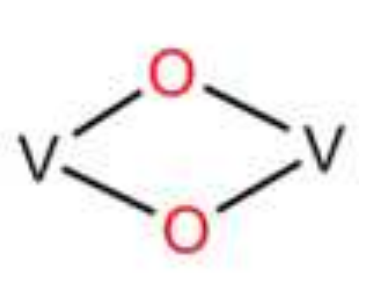

(4) 


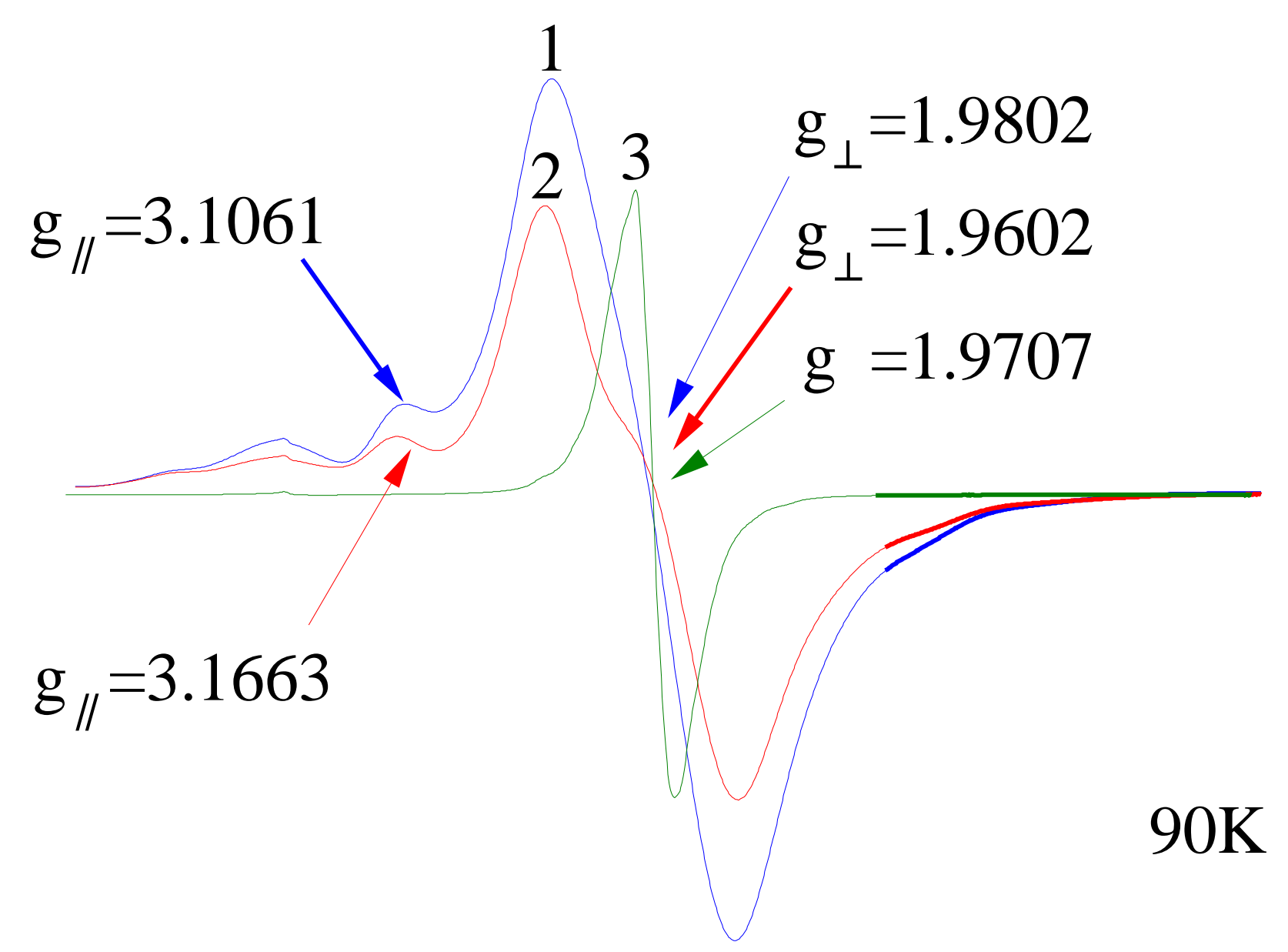

\begin{tabular}{ccccccccc}
\hline 0 & 1000 & 2000 & 3000 & 4000 & 5000 & 6000 & 7000 \\
$H($ Gass $)$
\end{tabular}




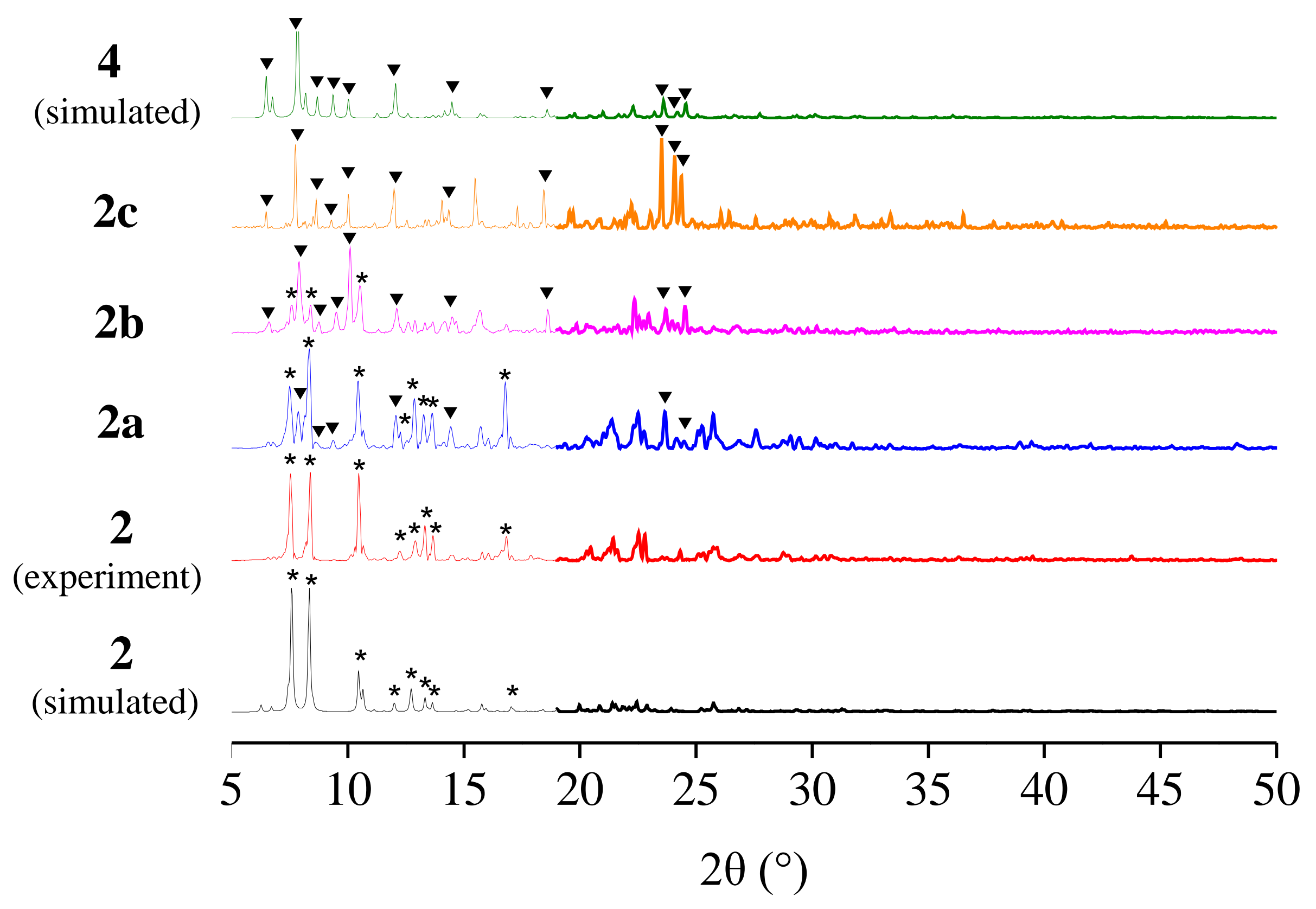




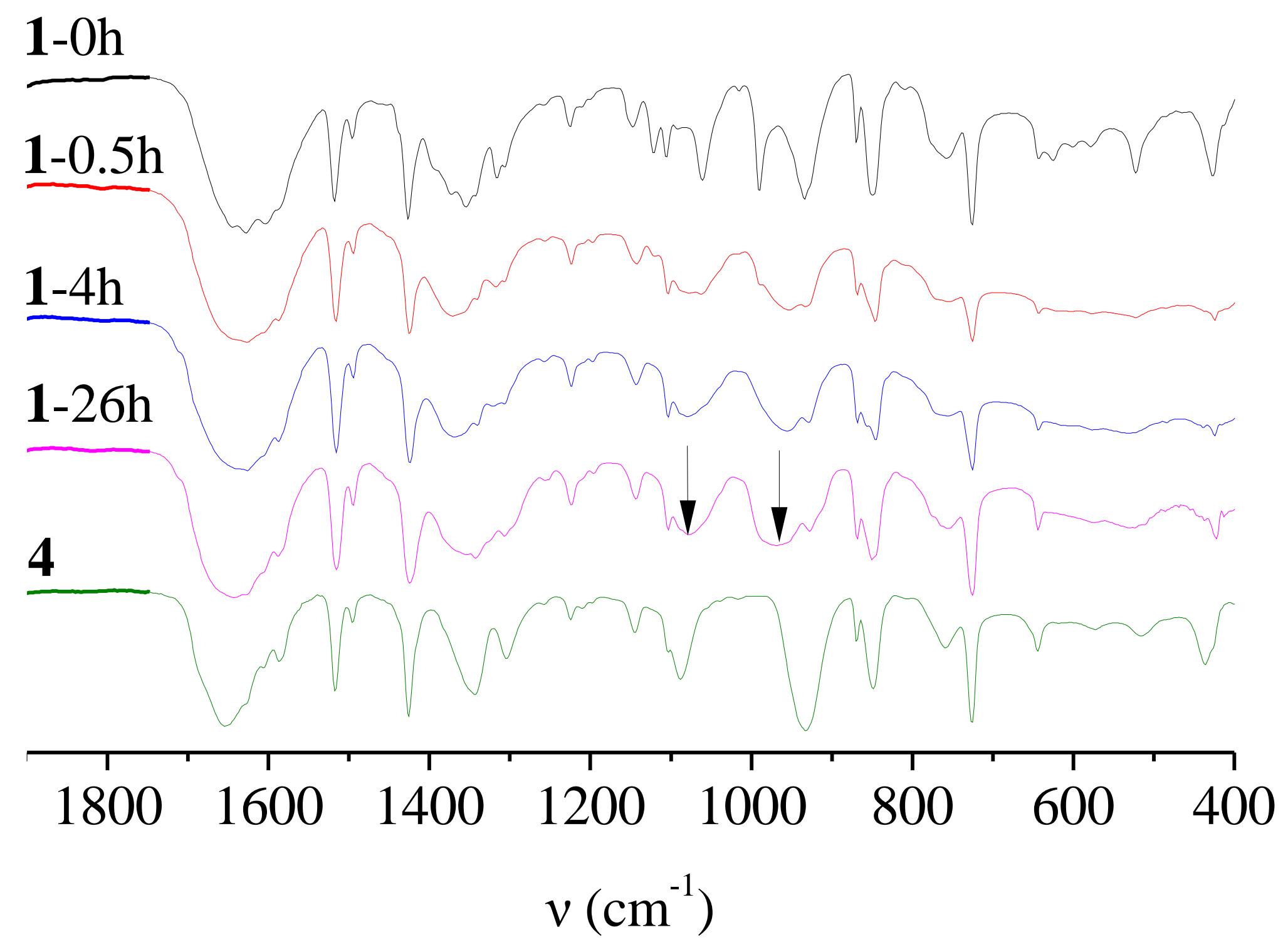

